\title{
The Effect of Theophylline on Regional Cerebral Blood Flow Responses to Hypoxia in Newborn Piglets
}

\author{
ANDREW J. MCPHEE AND GEORGE M. MAXWELL \\ Queen Victoria Hospital and Department of Paediatrics, University of Adelaide, Adelaide, South Australia
}

\begin{abstract}
Theophylline attenuates cerebral hypoxic hyperemia in several adult models and this is thought to be due to receptor-mediated antagonism of adenosine, a proposed mediator of hypoxic hyperemia. This attenuation of hypoxic hyperemia reduces cerebral oxygen delivery and may thus jeopardize cerebral oxidative metabolism. With these considerations in mind, and because theophylline is widely used in neonatal medicine, the present study was designed to investigate the effect of theophylline on regional cerebral blood flow, cerebral oxygen delivery, and cerebral metabolic rate for oxygen during normoxia and hypoxia in the newborn piglet model. In 16 newborn piglets, regional cerebral blood flow (microspheres) increased 250 $350 \%$ during hypoxia $\left(\mathrm{PaO}_{2}\right.$ 20-30 torr), while cerebral oxygen delivery and cerebral metabolic rate for oxygen were maintained at normoxic levels. Eight of these piglets were then given $10 \mathrm{mg} / \mathrm{kg}$ theophylline ethylenediamine intravenously and studies during normoxia and hypoxia were repeated; the remaining eight piglets served as time controls. Regional cerebral blood flow, cerebral oxygen delivery, and cerebral metabolic rate for oxygen during normoxia and hypoxia were not influenced by theophylline, despite plasma theophylline levels of 55-65 $\mu \mathrm{mol} / \mathrm{liter}$, and cerebrospinal fluid theophylline levels of 30-40 $\mu \mathrm{mol} / \mathrm{liter}$. These negative results are reassuring with respect to hypoxic cerebral blood flow control in theophylline-medicated infants. However, they do not support a role for adenosine as a mediator of cerebral hypoxic hyperemia in this model. (Pediatr Res 21: 573-578, 1987)
\end{abstract}

\section{Abbreviations}

CBF, cerebral blood flow

COD, cerebral oxygen delivery

$\mathrm{CMRO}_{2}$, cerebral metabolic rate for oxygen

MAP, mean arterial pressure

SSP, sagittal sinus pressure

CPP, cerebral perfusion pressure

ANOVA, analysis of variance

Theophylline is used widely in neonatal medicine, its uses include the treatment of apnea of prematurity $(1,2)$, the treatment of bronchopulmonary dysplasia (3), and the facilitation of weaning from mechanical ventilation (4-6). Several studies in adult models have shown that theophylline attenuates $\mathrm{CBF}$ re-

Received August 13, 1986; accepted January 6, 1987. Correspondence and reprint requests Dr. A. J. McPhee, Department of Paediatrics, Queen Victoria Hospital, 160 Fullarton Road, Rose Park, South Australia, 5067.

Supported by a grant from the Channel 10 Children's Medical Research Foundation. A.J.M. is supported by the Queen Victoria Hospital Research Foundation. sponses to hypoxia (7-9). This is thought to be due to theophylline's ability to act as an antagonist of specific cerebral vascular receptors for adenosine, the proposed tissue-derived mediator of cerebral hypoxic hyperemia (10), and as such these studies provide support for the adenosine hypothesis.

The increase in CBF during hypoxia is quantitative, with the arterial oxygen content and $\mathrm{CBF}$ being inversely related. Because of this, COD (the product of arterial oxygen content and CBF) is maintained constant during hypoxia, and this constitutes an important protective mechanism for the maintenance of cerebral oxidative metabolism (11). If theophylline attenuates CBF responses to hypoxia, then COD will not be maintained, and cerebral oxidative metabolism may be jeopardized. This is of some clinical concern, because such a situation may render the cerebral circulation prone to damage during hypoxia.

With these considerations in mind, the present study was designed to investigate the effect of theophylline on regional CBF responses to hypoxia and on the attendant changes in COD and $\mathrm{CMRO}_{2}$ in the newborn piglet model of CBF. In addition, as with comparable studies in adult models, the present study indirectly addressed the role of adenosine as a mediator of hypoxic hyperemia in this model.

\section{MATERIALS AND METHODS}

Animal preparation. Sixteen newborn piglets aged 1-5 days and weighing $1000-1790 \mathrm{~g}$ (mean $1340 \mathrm{~g}$ ) were used in the study. Venous access was secured under brief halothane (1-2\%) anesthesia. Thereafter, barbiturate anesthesia was established with intravenous sodium pentobarbital $25-35 \mathrm{mg} / \mathrm{kg}$ and maintained with small additional doses throughout the experiment. Rectal temperature was monitored and controlled to $39.0 \pm 0.5^{\circ} \mathrm{C}$ using an electrically heated operating surface and an overhead radiant heat source. Next, a tracheostomy was performed and mechanical ventilation with a $70 \% \mathrm{~N}_{2} / 30 \% \mathrm{O}_{2}$ gas mixture was begun at a rate of 60 breaths per min (Palmer Ventilator, London, England). The tidal volume was adjusted to maintain an arterial $\mathrm{pCO}_{2}$ of 30-40 torr. Polypropylene catheters (PE 50 Intramedic, Clay Adams, Parsippany, NJ) were then placed in the left femoral artery (to monitor arterial pressure), in the right femoral artery (for arterial sampling including the microsphere reference withdrawal specimen), and in the left ventricle via the left carotid artery (for microsphere injection). Studies have shown that ligation of a carotid artery does not influence differential hemispheric flow in this model $(12,13)$. Similarly in the present study, right hemispheric blood flow was $25.8 \pm 1.3 \mathrm{ml}(100 \mathrm{~g} \cdot \mathrm{min})^{-1}$ and left hemispheric blood flow was $25.9 \pm 1.3 \mathrm{ml}(100 \mathrm{~g} \cdot \mathrm{min})^{-1}$ during normoxia $(n=32)$, while flows of $70.7 \pm 3.7$ and $69.2 \pm$ $3.6 \mathrm{ml}(100 \mathrm{~g} \cdot \mathrm{min})^{-1}$, respectively, were seen during hypoxia $(n$ $=32$ ). Also, there was no effect of theophylline on differential hemispheric blood flow. Finally, the anterior fontanelle was exposed via a mid-saggital scalp incision, and a 22-gauge Teflon 
cannula (Jelco, Critikon, Tampa, FL) was advanced caudally into the sagittal sinus. This was used to measure sagittal sinus pressure and to sample cerebral venous blood. The animal was then placed in the left lateral position, and all vascular pressure calibrations were referenced to the midspinal level.

Experimental protocol. The experimental protocol for the study is shown in Figure 1. A 45- to 60-min recovery period followed the surgical preparation. Each animal was then studied during normoxia (normoxia $\mathrm{I}$, arterial $\mathrm{pO}_{2}>60$ torr). Following this, hypoxia was induced by decreasing fractional inspired oxygen to achieve an arterial $\mathrm{pO}_{2}$ of 20-30 torr, and further measurements were made (hypoxia I). These measurements were made $5 \mathrm{~min}$ after the induction of hypoxia, and because this degree of hypoxia regularly caused a decrease in arterial $\mathrm{pCO}_{2}$, supplementary $\mathrm{CO}_{2}$ was added to the inspired gases to maintain arterial $\mathrm{pCO}_{2}$ at $30-40$ torr. A 15 - to 20 -min recovery period followed this first hypoxic study. Half of the animals, the experimental group (EXP, $n=8$ ), were then given a bolus infusion of $10 \mathrm{mg} / \mathrm{kg}$ theophylline ethylenediamine (Aminophylline, David Bull Laboratories, Melbourne, Australia) diluted in 5\% dextrose to a concentration of $10 \mathrm{mg} / \mathrm{ml}$. The remaining animals, the control group (CON, $n=8$ ), were given an equivalent bolus of diluent. Twenty min later, studies were repeated during normoxia (normoxia II) and then hypoxia (hypoxia II) in both groups.

At each study period, cardiac output and regional CBF were determined using the reference organ modification of the radiolabeled microsphere technique (14). Immediately prior to each flow determination, arterial and sagittal sinus blood samples were drawn and analyzed for $\mathrm{pH}, \mathrm{pCO}_{2}$, and $\mathrm{pO}_{2}$ using a Corning 165 blood gas analyzer (Corning, Medfield, MA), and for hemoglobin concentration and \% oxygen saturation using an OSM 2 hemoximeter (Radiometer, Copenhagen, Denmark). The hemoglobin, $\mathrm{pO}_{2}$, and saturation results were used to calculate oxygen content (in vol \%) assuming a hemoglobin capacity of $1.34 \mathrm{vol} / \mathrm{g}$ and an oxygen solubility of $0.003 \mathrm{vol} / \mathrm{torr}$. These values were then used to calculate $\mathrm{COD}$ as flow $\times$ arterial $\mathrm{O}_{2}$ content, $\mathrm{CMRO}_{2}$ as flow $\times$ cerebral arteriovenous $\mathrm{O}_{2}$ content difference, and extraction fraction as the cerebral arteriovenous $\mathrm{O}_{2}$ content difference $\div$ arterial $\mathrm{O}_{2}$ content. After each flow determination, 2-4 $\mathrm{ml}$ of whole blood from a donor piglet were infused to replace sampling losses.

Arterial and sagittal sinus pressures were measured with precalibrated transducers (P23ID, Gould Inc, Cleveland, $\mathrm{OH}$ ), and were recorded continuously on a Gilson polygraph (Gilson Medical Electronics, Middleton, WI). Heart rate, MAP, and SSP were determined directly from the pressure tracing, and the CPP was calculated as MAP minus SSP. In the experimental group, plasma theophylline levels were determined with the normoxia II and hypoxia II measurements, and in three animals lumbar cerebrospinal fluid was sampled immediately after the hypoxia II measurements. Plasma and cerebrospinal fluid specimens were batched and theophylline levels were measured using fluorescent polarization methods (TDX, Abbott Laboratories Irving, TX). The intraassay coefficient of variation for levels in the range 40$150 \mu \mathrm{mol} /$ liter is less than $7 \%$ in our laboratories.

At the end of the experiment, each animal was rapidly killed by an overdose of sodium pentobarbital, and the brain was removed, weighed, and allowed to fix for 5-7 days in a $10 \%$ formalin solution. Thereafter the brain was dried, reweighed, and divided into left and right hemispheres, basal ganglia, cerebellum, and midbrain/brainstem. These tissues were dessicated at $120-150^{\circ} \mathrm{F}$ for $24-36 \mathrm{~h}$ and then packed into counting tubes.

Microsphere technique. The preparation and use of the microspheres followed the recommendations of Heymann et al. (15). Microspheres $15 \mu$ in diameter and labeled with ${ }^{51} \mathrm{Cr},{ }^{113} \mathrm{Sn},{ }^{85} \mathrm{Sr}$, ${ }^{95} \mathrm{Nb}$, or ${ }^{141} \mathrm{Ce}$ (Nentrac, New England Nuclear, Boston, MA) were used. The microspheres were suspended in normal saline containing $0.01 \%$ Tween 80 , with supplied stocks containing about 800,000 spheres $/ \mathrm{ml}$. A sample from each batch was examined by direct microscopy to confirm uniformity of size and absence of fragmented forms and aggregates. Standards were prepared from each batch and specific activity was determined in triplicate by counting spheres spread on a graph paper grid (15).

Preparation of the microspheres for injection involved withdrawal of a $1.0-\mathrm{ml}$ aliquot of the stock suspension followed by sonication and counting of each aliquot. Immediately prior to an injection, the microspheres were vigorously mixed for 30 $60 \mathrm{~s}$, drawn into a syringe, and injected via the left ventricular catheter over 10-15 s. The ventricular catheter was then flushed with $0.5 \mathrm{ml}$ of normal saline and its position verified from the pressure tracing. The reference withdrawal specimens were drawn beginning $10-15 \mathrm{~s}$ prior to, and continuing for $60-75 \mathrm{~s}$ after the injection, and the reference withdrawal rate was $1.23 \mathrm{ml} / \mathrm{min}$ (Orion, Cambridge, MA). Heart rate, arterial pressure, and pulse pressure were monitored throughout the injection and sampling periods to confirm the absence of arrhythmias or pressure changes. The order of the microsphere injections in a given experiment was determined using a computer generated random table.

The microsphere standards and the injection, withdrawal, and tissue specimens were counted in a well-type $\gamma$ counter $(118$ series, Nuclear Chicago, Des Plaines, IL), with the counting windows set to optimize counts for the individual microsphere species, and to minimize cross-overs. Specimens were kept to a height of less than $1 \mathrm{~cm}$ in order to maximize counting efficiency. The injection apparatus and injectate tube were counted and subtracted from the preinjection counts to determine the total counts injected. The reference withdrawal catheter, complete

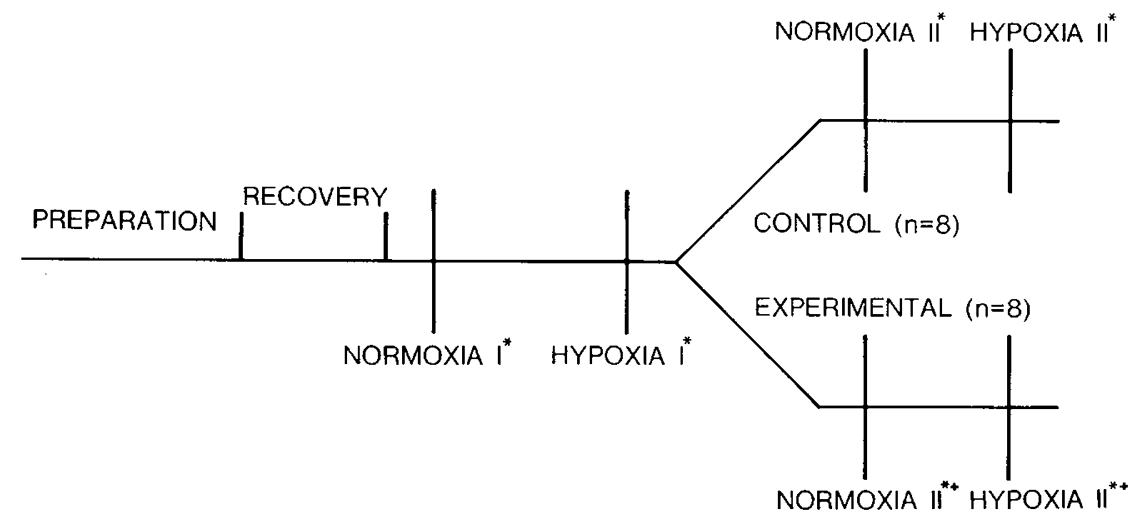

Fig. 1. Experimental protocol. At each study period $\left(^{*}\right)$ arterial and sagittal sinus blood gas analyses, hemoglobin, $\mathrm{O}_{2}$ saturation, vascular pressures, heart rate, regional $\mathrm{CBF}$, and cardiac output were determined. In the experimental group, serum theophylline levels were determined during normoxia II and hypoxia II (+). 
with the last sampled blood, was counted separately; absence of counts in this specimen was used to confirm completeness of sampling. The raw counts for the tissue specimens were corrected using the cross-overs derived from counting the standards. Cardiac output was determined as:

\section{$\mathrm{T} / \mathrm{R} \times \mathrm{W}$}

where $T$ is total cpm injected, $R$ is cpm in the reference withdrawal specimen, and $\mathrm{W}$ is the reference withdrawal rate $(1.23$ $\mathrm{ml} / \mathrm{min})$. The cardiac output is expressed as $\mathrm{ml}(\mathrm{kg} \cdot \mathrm{min})^{-1}$. Tissue sample blood flows were determined as:

$$
\mathrm{C} / \mathrm{R} \times \mathrm{W}
$$

where $\mathrm{C}$ is the corrected $\mathrm{cpm}$ in the tissue sample. All tissue flows are expressed as $\mathrm{ml}(100 \mathrm{~g} \cdot \mathrm{min})^{-1}$ formalin-fixed tissue. All tissue samples contained more than 400 microspheres, and all reference organ samples contained more than 2000 microspheres.

Criteria for the valid application of the microsphere technique in this laboratory were tested in a series of preliminary studies. Adequacy of mixing was tested by comparing counts in simultaneously drawn right brachial and left femoral arterial specimens. The ratio of upper limb to lower limb counts during normoxia was 0.99 (range $0.87-1.12, n=57$ ), and during hypoxia was 1.01 (range $0.90-1.10, n=28$ ), with no evidence of ductal right-to-left shunting. These results compare favorably with those of others (15-17). Cerebral and systemic arteriovenous bypass were tested by comparing counts in sagittal sinus or central venous specimens with those in a simultaneously drawn arterial specimen. Cerebral arteriovenous bypass averaged $0.6 \%$ (range $0-2.6 \%, n=22$ ), and systemic arteriovenous bypass averaged $1.0 \%$ (range $0-3.8 \%, n=25$ ). Neither cerebral nor systemic arteriovenous bypass was influenced by hypoxia.

Statistical analysis. The effect of hypoxia on blood gas, metabolic, hemodynamic, and regional $\mathrm{CBF}$ results was assessed by comparing the normoxia I and hypoxia I periods using paired $t$ tests. The effect of theophylline on hemodynamic and flow results during normoxia and hypoxia was determined by comparing the CON and EXP groups over all four study periods

Table 1. Blood gas, vascular pressures, heart rate, and cardiac output results during normoxia I and hypoxia I

\begin{tabular}{llcc}
\hline & & $\begin{array}{c}\text { Normoxia I } \\
(n=16)\end{array}$ & $\begin{array}{c}\text { Hypoxia I } \\
(n=16)\end{array}$ \\
\hline Arterial & $\mathrm{pH}$ & $7.53 \pm 0.02$ & $7.52 \pm 0.02$ \\
& $\mathrm{pCO}_{2}$ (torr) & $37.4 \pm 1.1$ & $37.1 \pm 1.2$ \\
& $\mathrm{pO}_{2}$ (torr) & $99.0 \pm 4.8$ & $23.1 \pm 1.0^{*}$ \\
& Hemoglobin & $8.8 \pm 0.3$ & $9.3 \pm 0.3^{*}$ \\
& $(\mathrm{~g} \% / 100 \mathrm{ml})$ & & \\
& $\mathrm{O}_{2}$ saturation & $98.0 \pm 0.5$ & $36.9 \pm 3.0^{*}$ \\
& $(\%)$ & & \\
& $\mathrm{O}_{2}$ content & $11.8 \pm 0.4$ & $4.7 \pm 0.4^{*}$ \\
& $($ vol \%) & & \\
Sagittal sinus & & & \\
& $\mathrm{pH}$ & $7.43 \pm 0.02$ & $7.47 \pm 0.02 \dagger$ \\
& $\mathrm{pCO}$ (torr) & $49.8 \pm 1.1$ & $44.0 \pm 1.2 \dagger$ \\
& $\mathrm{pO}$ (torr) & $23.7 \pm 1.3$ & $12.0 \pm 1.7^{*}$ \\
& $\mathrm{O}_{2}$ saturation & $35.8 \pm 3.1$ & $13.0 \pm 1.9^{*}$ \\
& $(\%)$ & & \\
& $\mathrm{O}_{2}$ content & $4.4 \pm 0.4$ & $1.7 \pm 0.3^{*}$ \\
MAP & $($ vol \%) & & \\
SSP & $(\mathrm{mm} \mathrm{Hg})$ & $64 \pm 3$ & $84 \pm 3^{*}$ \\
CPP & $(\mathrm{mm} \mathrm{Hg})$ & $5.4 \pm 0.4$ & $12.7 \pm 1.3^{*}$ \\
Heart rate & $(\mathrm{mm} \mathrm{Hg})$ & $59 \pm 3$ & $71 \pm 3^{*}$ \\
Cardiac output $\mathrm{ml}$ & $(\mathrm{min})^{-1}$ & $157 \pm 6$ & $213 \pm 7^{*}$ \\
\hline
\end{tabular}

${ }^{*} p<0.001, \dagger p<0.01$ for comparison with normoxia I (paired $t$ test). Results as mean \pm SEM.
Table 2. Regional cerebral blood flow ( $\mathrm{C} C B F)$, cerebral vascular resistance (CVR), $\mathrm{COD}, \mathrm{CMRO}_{2}$, and fractional oxygen extraction results for normoxia I and hypoxia I

\begin{tabular}{lcc}
\hline & $\begin{array}{c}\text { Normoxia I } \\
(n=16)\end{array}$ & $\begin{array}{c}\text { Hypoxia I } \\
(n=16)\end{array}$ \\
\hline rCBF ml $(100 \mathrm{~g} \cdot \mathrm{min})^{-1}$ & & \\
$\quad$ Cerebral hemispheres & $25.9 \pm 1.6^{*}$ & $71.5 \pm 5.9^{*} \dagger$ \\
Basal ganglia & $34.8 \pm 2.4$ & $101.4 \pm 9.2 \dagger$ \\
Cerebellum & $40.0 \pm 2.7$ & $112.7 \pm 10.6 \dagger$ \\
Midbrain-brainstem & $37.2 \pm 2.7$ & $127.3 \pm 13.0 \dagger$ \\
Whole brain & $28.7 \pm 1.8$ & $81.1 \pm 7.5 \dagger$ \\
CVR mm $\mathrm{Hg} \cdot 100 \mathrm{~g} \cdot \mathrm{min}(\mathrm{ml})^{-1}$ & $2.16 \pm 0.18$ & $0.97 \pm 0.11 \dagger$ \\
$\mathrm{COD}$ vol $(100 \mathrm{~g} \cdot \mathrm{min})^{-1}$ & $3.34 \pm 0.20$ & $3.54 \pm 0.25$ \\
$\mathrm{CMRO}_{2} \mathrm{vol}(100 \mathrm{~g} \cdot \mathrm{min})^{-1}$ & $2.09 \pm 0.12$ & $2.28 \pm 0.12$ \\
${\text { Fractional } \mathrm{O}_{2} \text { extraction }}$ & $0.63 \pm 0.04$ & $0.64 \pm 0.04$ \\
\hline
\end{tabular}

${ }^{*} p<0.05$ compared with other regions during each study period (ANOVA).

$\dagger p<0.001$ hypoxia I compared with normoxia I (paired t-test). Results as mean \pm SEM.

using 2-way ANOVA with repeated measures. Logarithmic transformations were used when indicated. ANOVA was also used to study differences in regional $\mathrm{CBF}$ at each study period. When significant effects were determined by ANOVA, further comparisons were made using the Waller-Duncan modification of the least significant difference rule (18). In all analyses, a $p$ level of $<0.05$ was considered significant, and all results are expressed as mean $\pm \mathrm{SEM}$.

\section{RESULTS}

Response to hypoxia. The results of the arterial and sagittal sinus blood gas analyses, vascular pressures, heart rate, and cardiac output measurements during the normoxia I and hypoxia I study periods are shown in Table 1 . The hypoxic manipulation produced the desired reduction in arterial $\mathrm{pO}_{2}$ to the $20-30$ torr range, and arterial oxygen content was reduced from $11.8 \pm 0.4$ to $4.7 \pm 0.4$ vol $\%(p<0.001)$. Arterial $\mathrm{pH}$ did not change and, by design, arterial $\mathrm{pCO}_{2}$ was maintained constant. The sagittal sinus $\mathrm{pO}_{2}$, oxygen saturation, and oxygen content also decreased during the hypoxic manipulation, and there was a significant decrease in sagittal sinus $\mathrm{pCO}_{2}$ with a corresponding increase in sagittal sinus $\mathrm{pH}$.

The hypoxic manipulation was also associated with significant increases in MAP, SSP, CPP, heart rate, and cardiac output. MAP increased from $64 \pm 3$ to $84 \pm 3 \mathrm{~mm} \mathrm{Hg}$, SSP from $5.4 \pm$ 0.4 to $12.7 \pm 1.3 \mathrm{~mm} \mathrm{Hg}$, CPP from $59 \pm 3$ to $71 \pm 3 \mathrm{~mm} \mathrm{Hg}$, heart rate from $157 \pm 6$ to $213 \pm 7$ beats $/ \mathrm{min}$, and cardiac output from $207 \pm 17$ to $270 \pm 20 \mathrm{ml}(\mathrm{kg} \cdot \mathrm{min})^{-1}(p<0.001$ for all comparisons).

The results of regional CBF, cerebral vascular resistance, $\mathrm{CMRO}_{2}, \mathrm{COD}$, and cerebral fractional oxygen extraction during normoxia I and hypoxia I are shown in Table 2. During the normoxia I studies, the hemispheric blood flow was significantly less than the flow to the other regions studied, and this pattern persisted at all other study periods. Hypoxia resulted in a marked increase in flow to all regions. Overall, whole brain blood flow, as determined from the regional flows, increased from $28.7 \pm$ $1.8 \mathrm{ml}(100 \mathrm{~g} \cdot \mathrm{min})^{-1}$ during normoxia I to $81.1 \pm 7.5 \mathrm{ml}(100$ $\mathrm{g} \cdot \mathrm{min})^{-1}$ during hypoxia $\mathrm{I}(p<0.001)$, and this increase in flow was associated with significant vasodilatation, as shown by the decrease in cerebral vascular resistance from $2.16 \pm 0.18$ to 0.97 $\pm 0.11 \mathrm{~mm} \mathrm{Hg} \cdot 100 \mathrm{~g} \cdot \min (\mathrm{ml})^{-1}(p<0.001)$. The COD, $\mathrm{CMRO}_{2}$, and fractional extraction of oxygen during hypoxia I were not different from those seen during normoxia $I$.

Effect of theophylline. Administration of theophylline ethylenediamine resulted in plasma theophylline levels of $61 \pm 5$ $\mu \mathrm{mol} /$ liter at normoxia II and $57 \pm 4 \mu \mathrm{mol} /$ liter at hypoxia II in 
the EXP group. The cerebrospinal fluid theophylline levels in the three samples obtained, were 42,35 , and $33 \mu \mathrm{mol} / 1$, representing 58,70 , and $53 \%$ of their respective plasma values. These CSF levels are consistent with plasma protein binding of 50$70 \%$ which is similar to that seen in premature newborns (19). The results of the arterial and sagittal sinus blood gas analyses, vascular pressures, heart rate, and cardiac output measurements for the CON and EXP groups during the normoxia II and hypoxia II study periods are shown in Table 3. Overall, there were no significant differences between the CON and EXP groups during each of the normoxia II and hypoxia II study periods, although heart rate and cardiac output did tend to be higher in the EXP group. When the normoxia I results were compared with the normoxia II results, and the hypoxia I results with the hypoxia II results, the only significant difference detected was a small decrease in arterial $\mathrm{pH}$ during the second study periods. In both the CON and EXP group, the changes and responses during the normoxia II/hypoxia II study were similar to those seen during the normoxia I/hypoxia I study, although the increase in MAP (and consequently CPP) during the normoxia II/hypoxia II study appeared less than that seen during the earlier study.

The regional $\mathrm{CBF}$ results for the $\mathrm{CON}$ and EXP groups during the normoxia II and hypoxia II study periods are shown in Figure 2. The regional $\mathrm{CBF}$ values in the $\mathrm{CON}$ and EXP groups during normoxia II are similar, and comparison with the corresponding values during normoxia I revealed no differences. During hypoxia II, regional CBF increased similarly in both the CON and EXP groups, and again these flow increases were not different from those seen during hypoxia I. The results of cerebral vascular resistance, cerebral $\mathrm{O}_{2}$ delivery, $\mathrm{CMRO}_{2}$, and fractional extraction of $\mathrm{O}_{2}$ during the normoxia II/hypoxia II study were similar to those seen in the early study, and again, no difference between the CON and EXP groups was evident for any of these measurements. Thus, during the normoxia II/hypoxia II study, CVR decreased from $2.47 \pm 0.40$ to $0.97 \pm 0.14 \mathrm{~mm} \mathrm{Hg} \cdot 100 \mathrm{~g} \cdot \mathrm{min}$ $(\mathrm{ml})^{-1}$ in the CON group and from $2.15 \pm 0.20$ to $0.84 \pm 0.07$ $\mathrm{mm} \mathrm{Hg} \cdot 100 \mathrm{~g} \cdot \mathrm{min}(\mathrm{ml})^{-1}$ in the EXP group. The COD, $\mathrm{CMRO}_{2}$, and fractional extraction of oxygen results during normoxia II were $3.24 \pm 0.33 \mathrm{vol}(100 \mathrm{~g} \cdot \mathrm{min})^{-1}, 1.97 \pm 0.19 \mathrm{vol}(100 \mathrm{~g}$. $\mathrm{min}^{-1}$ and $0.61 \pm 0.04$ in the CON group, and $3.27 \pm 0.15 \mathrm{vol}$ $(100 \mathrm{~g} \cdot \mathrm{min})^{-1}, 1.95 \pm 0.16 \mathrm{vol}(100 \mathrm{~g} \cdot \mathrm{min})^{-1}$ and $0.60 \pm 0.05$ in the EXP group. The corresponding results during hypoxia II were $3.26 \pm 0.24,2.18 \pm 0.17$, and $0.67 \pm 0.03$ in the CON group, and $3.17 \pm 0.22,2.23 \pm 0.16$, and $0.70 \pm 0.02$ in the EXP group.

\section{DISCUSSION}

Because barbiturate anesthesia has a marked effect on both $\mathrm{CBF}$ and $\mathrm{CMRO}_{2}$, the implications of its use in the present study deserve comment. Barbiturate anesthesia produces parallel dosedependent reductions in both $\mathrm{CBF}$ and $\mathrm{CMRO}_{2}$ and this is thought to be a passive reflection of its direct effect on cerebral function (20). Although the effects of barbiturate anesthesia on $\mathrm{CBF}$ and $\mathrm{CMRO}_{2}$ were not addressed directly in the present study, comparison of our results with those of others suggests a similar parallel reduction in $\mathrm{CBF}$ and $\mathrm{CMRO}_{2}$ during barbiturate anesthesia in the newborn piglet model. Thus, studies in acute unanesthetized piglets have shown an average CBF of $80-110$ $\mathrm{ml}(100 \mathrm{~g} \cdot \mathrm{min})^{-1}(13,21-24)$ and $\mathrm{CMRO}_{2}$ of 5.7-6.0 vol $(100$ $\mathrm{g} \cdot \mathrm{min})^{-1}(21,25)$ while in the present study $\mathrm{CBF}$ and $\mathrm{CMRO}_{2}$ were proportionately reduced to $25-30 \mathrm{ml}(100 \mathrm{~g} \cdot \mathrm{min})^{-1}$ and $2.09 \mathrm{vol}(100 \mathrm{~g} \cdot \mathrm{min})^{-1}$, respectively. These considerably lower baseline $\mathrm{CMRO}_{2}$ and flow values raise the question of the influence of anaesthesia with respect to the aims of the present study, namely the investigation of the effect of theophylline on cerebral hypoxic hyperemia, and by inference, the role of adenosine as a mediator of this hyperemia. However, as the results in the normoxia I/hypoxia I phase of the present study show, barbiturate anaesthesia does not interfere with the inverse relationship between arterial $\mathrm{O}_{2}$ content and CBF which has been demonstrated in a number of studies in unanaesthetized models. In these studies as in ours, the response of the cerebral circulation to a decrease in arterial $\mathrm{O}_{2}$ content is an increase in flow, such that $\mathrm{COD}$ is maintained constant, and $\mathrm{CMRO}_{2}$ is preserved without an increase in fractional extraction of oxygen (11). Because it is unlikely that the preservation of this relationship is achieved through different vasoregulatory mechanisms in anaesthetized compared with unanaesthetized animals, we do not believe that the use of barbiturate anaesthesia detracts from addressing the questions posed in this study.

In the present study, the administration of $10 \mathrm{mg} / \mathrm{kg}$ theo-

Table 3. Blood gas, vascular pressures, heart rate, and cardiac output results in the CON and EXP groups during the normoxia II and hypoxia II study periods

\begin{tabular}{|c|c|c|c|c|}
\hline & \multicolumn{2}{|c|}{ Normoxia II } & \multicolumn{2}{|c|}{ Hypoxia II } \\
\hline & $\begin{array}{c}\mathrm{CON} \\
(n=8)\end{array}$ & $\begin{array}{c}\text { EXP } \\
(n=8)\end{array}$ & $\begin{array}{c}\mathrm{CON} \\
(n=8)\end{array}$ & $\begin{array}{c}\text { EXP } \\
(n=8)\end{array}$ \\
\hline \multicolumn{5}{|l|}{ Arterial } \\
\hline $\mathrm{pH}$ & $7.49 \pm 0.02^{*}$ & $7.48 \pm 0.02^{*}$ & $7.50 \pm 0.02$ & $7.46 \pm 0.02 *$ \\
\hline $\mathrm{PCO}_{2}$ (torr) & $36.9 \pm 1.2$ & $38.6 \pm 0.8$ & $36.0 \pm 1.0$ & $38.0 \pm 0.8$ \\
\hline $\mathrm{pO}_{2}$ (torr) & $94.5 \pm 5.7$ & $93.3 \pm 6.7$ & $22.3 \pm 0.8 \dagger$ & $24.5 \pm 1.4 \dagger$ \\
\hline $\mathrm{Hb}(\mathrm{g} / 100 \mathrm{ml})$ & $9.0 \pm 0.4$ & $8.4 \pm 0.3$ & $9.6 \pm 0.4 \ddagger$ & $8.7 \pm 0.3 \ddagger$ \\
\hline $\mathrm{O}_{2}$ saturation (\%) & $97.9 \pm 0.6$ & $97.0 \pm 0.9$ & $35.1 \pm 2.7 \dagger$ & $36.1 \pm 3.2 \dagger$ \\
\hline $\mathrm{O}_{2}$ content (vol \%) & $12.1 \pm 0.5$ & $11.2 \pm 0.5$ & $4.5 \pm 0.4 \dagger$ & $4.3 \pm 0.4 \uparrow$ \\
\hline \multicolumn{5}{|l|}{ Sagittal sinus } \\
\hline $\mathrm{pH}$ & $7.41 \pm 0.02$ & $7.40 \pm 0.02$ & $7.46 \pm 0.02 \ddagger$ & $7.42 \pm 0.02$ \\
\hline $\mathrm{pCO}_{2}$ (torr) & $47.9 \pm 1.3$ & $50.3 \pm 0.7$ & $42.1 \pm 1.6 \neq$ & $45.5 \pm 0.9+$ \\
\hline $\mathrm{pO}_{2}$ (torr) & $24.1 \pm 1.6$ & $25.0 \pm 1.9$ & $12.0 \pm 1.5 \dagger$ & $10.5 \pm 0.9 \dagger$ \\
\hline $\mathrm{O}_{2}$ saturation $(\%)$ & $38.6 \pm 3.5$ & $37.9 \pm 5.0$ & $11.5 \pm 1.5 \dagger$ & $10.6 \pm 1.0 \dagger$ \\
\hline $\mathrm{O}_{2}$ content (vol \%) & $4.8 \pm 0.6$ & $4.4 \pm 0.7$ & $1.5 \pm 0.2 \dagger$ & $1.3 \pm 0.1 \dagger$ \\
\hline $\mathrm{MAP}(\mathrm{mm} \mathrm{Hg})$ & $66 \pm 4$ & $65 \pm 3$ & $79 \pm 5 \dagger$ & $74 \pm 4 \ddagger$ \\
\hline $\mathrm{SSP}(\mathrm{mm} \mathrm{Hg})$ & $5.1 \pm 0.4$ & $5.6 \pm 0.4$ & $10.3 \pm 0.9 \dagger$ & $11.2 \pm 1.4 \dagger$ \\
\hline $\mathrm{CPP}(\mathrm{mm} \mathrm{Hg})$ & $61 \pm 4$ & $60 \pm 3$ & $68 \pm 6$ & $63 \pm 5$ \\
\hline Heart rate $(\min )^{-1}$ & $150 \pm 6$ & $180 \pm 12$ & $218 \pm 13 \dagger$ & $227 \pm 10 \dagger$ \\
\hline $\begin{array}{l}\text { Cardiac output } \\
\mathrm{ml}(\mathrm{kg} \cdot \mathrm{min})^{-1}\end{array}$ & $171 \pm 20$ & $216 \pm 31$ & $228 \pm 23 \ddagger$ & $275 \pm 36 \ddagger$ \\
\hline
\end{tabular}

$* p<0.05$ for comparison with corresponding group during normoxia I or hypoxia I (ANOVA).

$\dagger p<0.01, \ddagger p<0.05$ hypoxia II compared with normoxia II for each group. Results as mean $\pm \mathrm{SEM}$. 


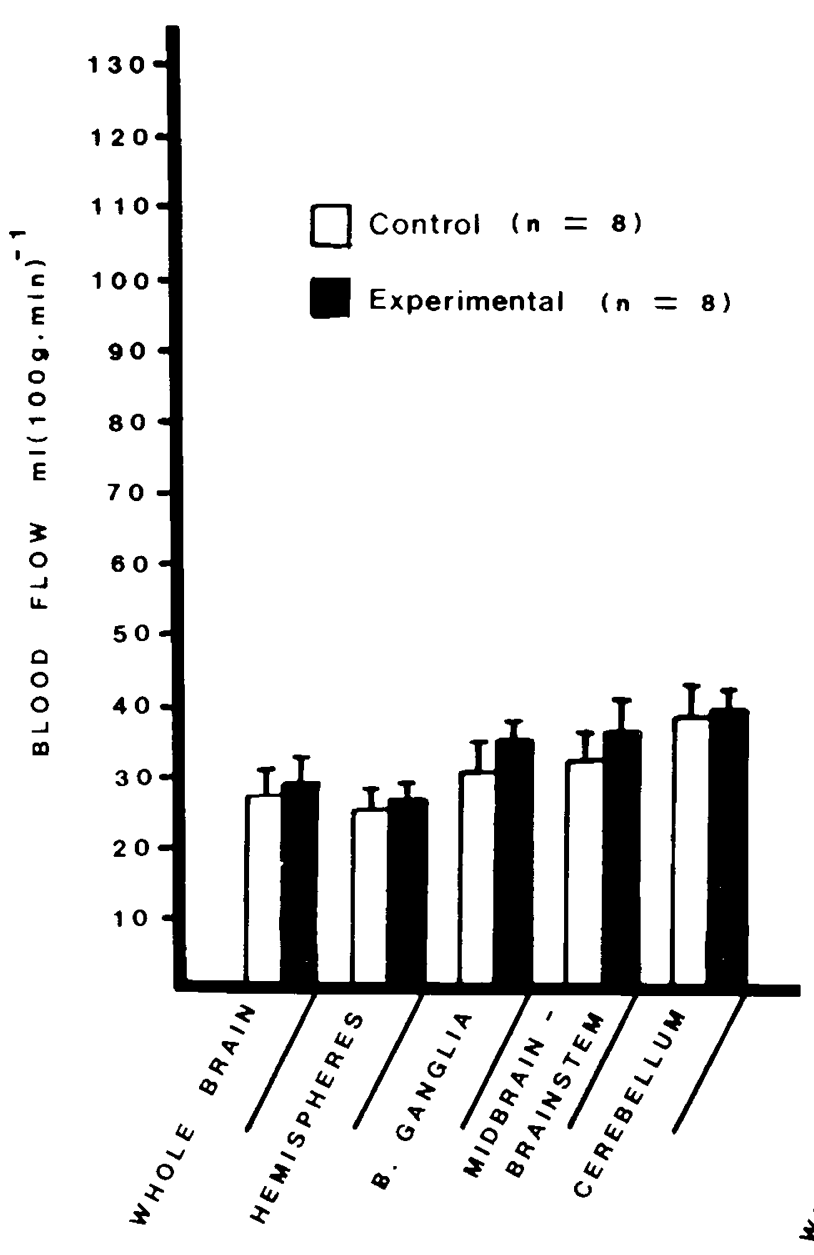

NORMOXIA II

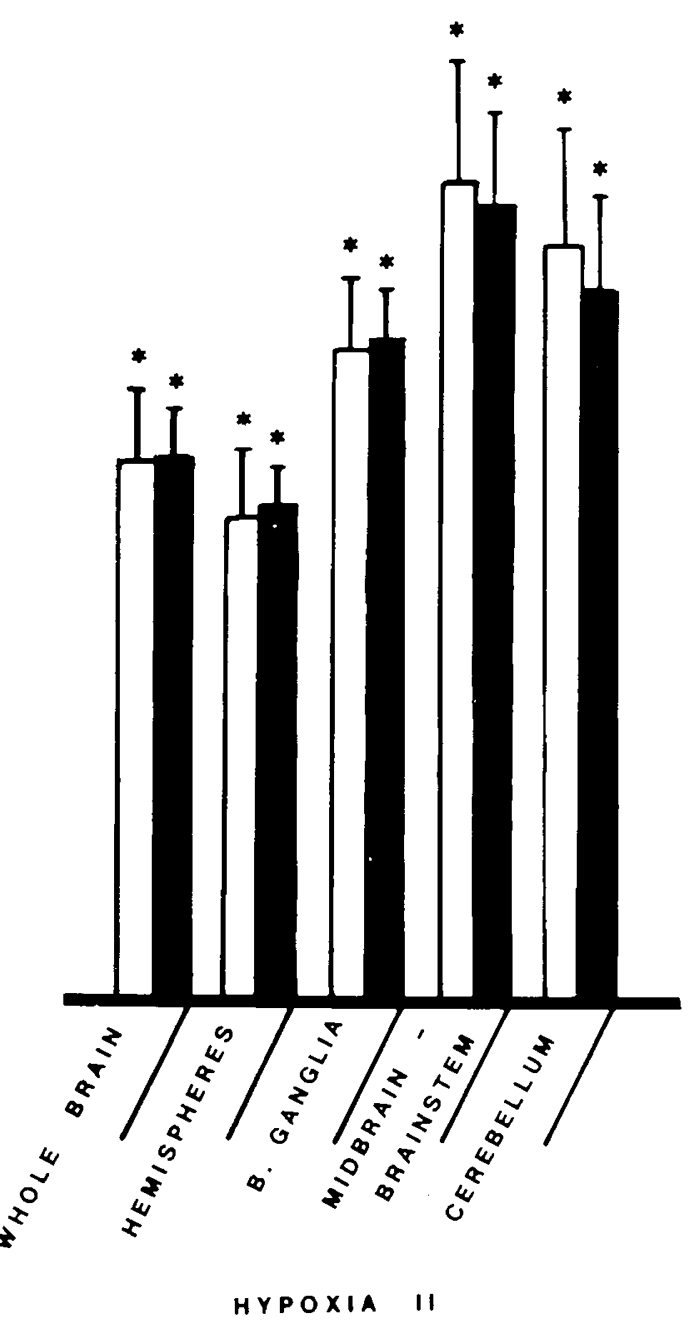

Fig. 2. Regional CBF results for the CON and EXP groups during the normoxia II and hypoxia II study periods. ${ }^{*} p<0.01$ compared to corresponding normoxia II measurement (ANOVA). Results as mean \pm SEM.

phylline ethylenediamine did not affect regional $\mathrm{CBF}$ and $\mathrm{CMRO}_{2}$ during normoxia. These findings agree with those from a comparable study in piglets given $6 \mathrm{mg} / \mathrm{kg}$ theophylline ethylenediamine (25) and argue against a direct cerebral vascular or metabolic effect of theophylline at this dose.

The effect of theophylline on cerebral hypoxic hyperemia is pertinent, albeit indirectly, to the proposed role of adenosine as a mediator of hypoxic hyperemia (10). Adenosine is a potent vasodilator, is produced during hypoxia, and is thought to exert its vascular effects via an interaction with specific receptors (adenosine $\mathrm{A}_{2}$ receptors) on vascular smooth muscle $(10,26)$. Considevable indirect evidence for the adenosine hypothesis of cerebral hypoxic vasoregulation has come from studies using pharmacologic agents which either alter perivascular adenosine concentrations, or antagonize adenosine at the receptor level. The ability of such agents to alter vascular responses to adenosine and to alter flow responses to hypoxia has been advanced as evidence of the role of adenosine as a vasoregulator (27-29), although some controversy exists (30).

Similarly theophylline, an adenosine $\mathrm{A}_{2}$ receptor antagonist, has been shown to attenuate adenosine-mediated vasodilatation and flow responses to hypoxia. Thus in vitro, theophylline 30 $100 \mu \mathrm{mol} /$ liter attenuates adenosine induced vasodilation of $\mathrm{KCl}$-contracted rabbit coronary arteries (26), and similar concentrations of theophylline block adenosine mediated actions at other $\mathrm{A}_{2}$ receptor sites (31). In vivo, micropipette studies of pial arterioles in adult cats have shown that theophylline $50 \mu \mathrm{mol} /$ liter attenuates the vasodilatation induced by physiologically relevent levels of adenosine (0.1-1.0 $\mu \mathrm{mol} / \mathrm{liter})(32)$, and several studies have shown that theophylline can attenuate CBF responses to hypoxia. In adult rats, hypoxic hyperemia was inhibited in the presence of a cerebrospinal fluid theophylline concentration of $50 \mu \mathrm{mol} /$ liter (9). Also the intracerebrovascular infusion of theophylline $1 \mu \mathrm{g} / \mathrm{min}$ markedly attenuated hypoxic hyperemia in rats (8) while a similar infusion of $20 \mu \mathrm{g} / \mathrm{min}$ in adult dogs (7) blocked the flow response to moderate hypoxia (arterial $\mathrm{pO}_{2} 47$ torr) and partially blocked the flow response to severe hypoxia (arterial $\mathrm{pO}_{2} 20$ torr). Although the theophylline concentrations resulting from these intracerebrovascular infusions were not determined, estimates based on the infusion rate and flow results can be made. Thus, in adult dogs (7), an infusion of $20 \mu \mathrm{g} / \mathrm{min}$ and a CBF of $30 \mathrm{ml} / \mathrm{min}$ would result in a blood theophylline concentration of $0.7 \mu \mathrm{g} / \mathrm{ml}$ (about 3-4 $\mu \mathrm{mol} / \mathrm{liter}$ ), while a concentration of about $5 \mu \mathrm{mol} /$ liter can be estimated in the study in adult rats (8). Overall these studies of the effects of theophylline on adenosine-mediated vasodilation and hypoxic hyperemia support the adenosine hypothesis. Moreover, from a clinical perspective, theophylline exerts these effects at therapeutically relevant concentrations (1), and clearly alters the relationship between CBF and arterial oxygen content. Inasmuch as this relationship is important for the maintenance of COD and $\mathrm{CMRO}_{2}$, this effect of theophylline has potential adverse effects with respect to cerebral oxidative metabolism.

In the present study, theophylline did not influence regional CBF responses to hypoxia, despite plasma levels of $55-65 \mu \mathrm{mol} /$ liter, which are in the high therapeutic range for the treatment 
of apnea of prematurity (1). Our inability to show that theophylline compromises regional $\mathrm{CBF}$ and $\mathrm{COD}$ during hypoxia, as suggested by the adult studies cited above, is reassuring with respect to the theophylline-medicated neonate. However, the results do not provide support for the adenosine hypothesis. Possible explanations for our negative findings include the choice of anesthesia, the model used, the dosage and route of administration of theophylline, and the possibility of confounding effects of theophylline. The implications of barbiturate anaesthesia have already been discussed; in addition, barbiturate anaesthesia was used in a study supporting the hypothesis in adult dogs (7). A species effect of adenosine seems unlikely, particularly in view of a recent study in newborn piglets in which a different manipulation of interstitial adenosine produced evidence in favor of the adenosine hypothesis (29).

With respect to the dosage and route of administration of theophylline, there are obvious differences between our study and those studies using intracerebrovascular infusions and topical theophylline. However, the interstitial fluid theophylline concentration is the critical determinant of receptor antagonism, and assuming that the cerebrospinal fluid theophylline concentration approximates the interstitial fluid concentration, then interstitial fluid concentrations of $30-40 \mu \mathrm{mol} / \mathrm{liter}$ were achieved in the present study. This is comparable to the concentration which attenuated adenosine-mediated vasodilatation and hypoxic hyperemia in adult cats (32) and rats (9), and is considerably higher than those estimated in the studies using intracerebrovascular theophylline $(7,8)$. Nevertheless, because the theophylline concentration required to block the cerebral vasodilation produced by physiologically relevant levels of adenosine in the piglet is unknown, it is possible that our negative results reflect inadequate perivascular theophylline levels. Further studies investigating the dose-response relationship between theophylline and exogenous adenosine, and perhaps using more potent receptor antagonists such as 8-phenyltheophylline (33) are indicated. The possibility of confounding vascular or metabolic effects of theophylline is suggested by similar discrepancies when theophylline has been used to study flow control in other tissues in which adenosine is proposed to subserve vasoregulatory functions $(33,34)$. Such discrepancies suggest caution in the interpretation of our negative results with respect to the adenosine hypothesis. Finally, a recent report in which neither intraperitoneal theophylline $(30-35 \mathrm{mgm} / \mathrm{kg}$ ) nor cortical superfusion with $100 \mu \mathrm{mol} /$ liter theophylline altered cerebrocortical flow responses to hypoxia in adult cats (35), is in agreement with our study. Overall, it is difficult to reconcile these conflicting studies and unfortunately the results of the present study only add to the controversy of the role of adenosine in cerebral hypoxic vasoregulation.

In summary, regional $\mathrm{CBF}$ and $\mathrm{CMRO}_{2}$ during normoxia and hypoxia were not affected by pretreatment with theophylline ethylenediamine $10 \mathrm{mg} / \mathrm{kg}$ in barbiturate anaesthetized newborn piglets. The levels of theophylline achieved were in the high therapeutic range for the treatment of apnea of prematurity and the absence of an effect on hypoxic hyperemia is reassuring with respect to the apneic infant. While the results of this study do not support a role for adenosine as a mediator of hypoxic hyperemia in the newborn model of CBF, further studies using more potent receptor antagonists and other pharmacologic manipulations of perivascular adenosine are indicated in order to further investigate this hypothesis.

Acknowledgments. The authors thank Ms. Jennifer Blake for technical assistance and Mrs. Carole Whan for her excellent secretarial assistance in the preparation of this manuscript.

\section{REFERENCES}

1. Roberts RJ 1984 Methyl xanthine therapy: caffeine and theophylline. In: Drug Therapy in Infants-Pharmacologic Principles and Clinical Experience. WB Saunders Co, Philadelphia, 119-137

2. Aranda JV, Turmen $T 1979$ Methylxanthines in apnea of prematurity. Clin Perinatol 6:87-108

3. Rooklin AR, Moomjian AS, Shutack JG, Shwartz JG, Fox WW 1979 Theo- phylline therapy in bronchopulmonary dysplasia. J Pediatr 95:882-885

4. Harris MC, Baumgart S, Rooklin AR, Fox WW 1983 Successful extubation of infants with respiratory distress syndrome using aminophylline. $J$ Pediatr 103:303-305

5. Greenough A, Elias-Jones J, Pool J, Morley CJ, Davis JA, 1985 The therapeutic actions of theophylline in preterm ventilated infants. Early Hum Dev 12:1522

6. Viscardi RM, Faix RG, Nicks JJ, Grasela TH 1985 Efficacy of theophylline for prevention of post-extubation respiratory failure in very low birth-weight infants. J Pediatr 107:469-472

7. Emerson TE, Raymond RM 1981 Involvement of adenosine in cerebra hypoxic hyperemia in the dog. Am J Physiol 241:H134-H138

8. Hoffman WE, Albrecht RF, and Miletich DJ 1984 The role of adenosine in CBF increases during hypoxia in young vs aged rats. Stroke 15:124-129

9. Morii S, Winn HR, Berne RM 1983 Effect of theophylline, an adenosine receptor blocker, on cerebral blood flow (CBF) during rest and transient hypoxia. J Cereb Blood Flow Metab 3(suppl 1):S480-S481

10. Winn HR, Rubio GR and Berne RM 1981 Editorial: The role of adenosine in the regulation of cerebral blood flow. J Cereb Blood Flow Metab 1.239-244

11. Jones MD, Traystman RJ 1984 Cerebral oxygenation of the fetus, newborn and adult. Semin Perinatol 8:205-219

12. Laptook AR, Stonestreet BS, Oh W 1983 The effect of carotid artery ligation on brain blood flow in newborn piglets. Brain Res 276:51-54

13. Leffler CW, Busija DW, Fletcher AM, Beasley DG, Hessler JR, Green RS 1985 Effects of indomethacin upon cerebral hemodynamics of newborn pigs. Pediatr Res 19:1160-1164

14. Archie JP, Fixler DE, Ullyot DJ, Hoffman JI, Utley JR, Carlson EL 1973 Measurement of cardiac output with and organ trapping of radioactive microspheres. J Appl Physiol 35:148-154

15. Heymann MA, Payne BD, Hoffman JIE, Rudolph AM 1977 Blood flow measurements with radionuclide-labelled particles. Prog Cardiovasc Dis 20:55-79

16. Laptook A, Stonestreet B, Oh W 1982 Autoregulation of brain blood flow in the newborn piglet: regional differences in flow reduction during hypotension. Early Hum Dev 6:99-107

17. Buckberg GD, Luck JC, Payne DB, Hoffman JIE, Archie JP, Fixler DE 1971 Some sources of error in measuring regional blood flow with radioactive microspheres. J Appl Physiol 31:598-604

18. Waller RA, Duncan DB 1969 A Bayes rule for the symmetric multiple comparisons problem. J Am Stat Assoc 64:1484-1503

19. Aranda JV, Sitar DS, Parsons WD, Loughnan PM, Neims AH 1976 Pharmacokinetic aspects of theophylline in premature newborns. N Engl J Med 295:413-416

20. Michenfelder JD 1974 The interdependency of cerebral function and metabolic effects following massive doses of thiopental in the dog. Anesthesiology 41:231-236

21. Hansen NB, Nowicki PT, Miller RR, Malone T, Bickers RG, Menke JA 1986 Alterations in cerebral blood flow and oxygen consumption during prolonged hypocarbia. Pediatr Res 20:147-150

22. Hansen NB, Brubakk A, Bratlid D, Oh W, Stonestreet BS 1984 The effects of variations in $\mathrm{PaCO}_{2}$ on brain blood flow and cardiac output in the newborn piglet. Pediatr Res 18:1132-1136

23. Brubakk A, Bratlid D, Oh W, Yao AC, Stonestreet BS 1984 Atropine prevents increases in brain blood flow during hypertension in newborn piglets. Pediatr Res 18:1121-1126

24. Laptook A, Stonestreet BS, Oh W 1982 The effects of different rates of plasmanate infusions upon brain blood flow after asphyxia and hypotension in newborn piglets. J Pediatr 100:791-796

25. Stonestreet BS, Nowicki PT, Hansen NB, Petit R, Oh W 1983 Effect of aminophylline on brain blood flow in the newborn piglet. Dev Pharmacol Ther 6:248-258

26. Odawara S, Kurahashi K, Usui H, Taniguchi T, Fujiwara M 1986 Relaxations of isolated rabbit coronary artery by purine derivatives: $A_{2}$-adenosine receptors. J Cardiovasc Pharmacol 8:567-573

27. Phillis JW, DeLong RE, Towner KJ 1985 Adenosine deaminase inhibitors enhance cerebral anoxic hyperemia in the rat. J Cereb Blood Flow Metab 5:295-299

28. Phillis JW, Preston G, DeLong RE 1984 Effects of anoxia on cerebral blood flow in the rat brain: evidence for a role of adenosine in autoregulation. $J$ Cereb Blood Flow Metab 4:586-592

29. Wagerle LC, Mishra OP 1986 Adenosine mediation of the cerebral arteriolar response to hypoxemia in newborn piglets. Pediatr Res 20:210(abstr)

30. Dora E, Koller A, Kovach AGB 1984 Effect of topical adenosine deaminase treatment on functional hyperemic and hypoxic responses of cerebrocortical microcirculation. J Cereb Blood Flow Metab 4:447-457

31. Schwabe U, Ukena D, Lohse MJ 1985 Xanthine derivatives as antagonists at $A_{1}$ and $A_{2}$ adenosine receptors. Naunyn Schmiedebergs Arch Pharmacol 330:212-22

32. Wahl M, Kuschinsky W 1976 The dilatatory action of adenosine on pial arterioles of cats and its inhibition by theophylline. Pfluegers Arch 362:5559

33. Lautt WW, Legare DJ 1985 The use of 8-phenyltheophylline as a competitive antagonist of adenosine and an inhibitor of the intrinsic regulatory mechanism of the hepatic artery. Can J Physiol Pharmacol 63:717-722

34. Berne RM 1980 The role of adenosine in the regulation of coronary blood flow. Circ Res 47:807-813

35. Kovach AGB, Dora E 1986 Effects of theophylline on hypoxic and functional hyperemic responses of cerebrocortical microcirculation. Physiologist 28:360(abstr) 